\title{
Recombinant Interferon Alfa-2b
}

National Cancer Institute

\section{Source}

National Cancer Institute. Recombinant Interferon Alfa-2b. NCI Thesaurus. Code C1953.

A non-glycosylated recombinant interferon with antiviral and antineoplastic activities. Alfa interferons bind to specific cell-surface receptors, resulting in the transcription and translation of genes whose protein products mediate antiviral, antiproliferative, anticancer, and immune-modulating effects. 